\title{
Relationship Between Motivation and Discipline of Students to Student Learning Outcomes Class XI Vocational High School
}

\author{
Puji Astuti \\ Sekolah Tinggi Ilmu Kesehatan Bina Husada Palembang \\ astutifuji22@yahoo.com
}

\begin{abstract}
Learning outcomes are used as benchmarks used to measure students' success in bsorbing lessons and as an evaluation material for teachers in delivering learning material. Student learning outcomes can be influenced by various factors such as learning discipline factors and student motivation factors. The purpose of the study was to see how the students' motivation and discipline relate to the results of learning English class students XI of SMK Bina Bangsa Kayuagung OKI. The design of this study was quantitative descriptive with cross sectional. Data collection uses secondary data. Data analysis techniques were processed by chi-square test with a significant level of 95 and the largest error rate $(\alpha)$ of 0.05 or $5 \%$. The results of the analysis of learning motivation towards students' learning outcomes in English were obtained $\rho$-value 1,000 ( $>\alpha 0.05)$ and learning discipline towards students' English learning outcomes obtained $\rho$-value $0.142(>\alpha 0.05)$ it means that there is no meaningful relationship between motivation and learning discipline with the results of learning English in class XI SMK Bina Bangsa Kayuagung OKI. Students should improve and have curiosity and care about the acquisition of learning values. For schools to always provide opportunities and motivations for teachers to do more self-development which later can contribute positively to improving student learning outcomes.
\end{abstract}

Key words: motivation, discipline, learning outcomes. 


\section{INTRODUCTION}

Efforts to realize the purpose of implementing education are to create quality human resources and character as well as having noble character can be achieved if students have good learning achievements. Learning achievement is used as a benchmark used to measure student success in absorbing lessons and as an evaluation material for teachers in delivering learning material so that there is an increase in learning achievement from year to year. Student achievement can be influenced by various factors, but factors that greatly affect student learning achievement usually arise from within students. Some of these factors include learning discipline factors and student motivation factors.

According to Moenir (2010) that discipline is a form of obedience to rules, whether in writing or not in accordance with what has been determined. Hasibuan (2003) states discipline is a sense of selfawareness and the will of the individual to apply applicable norms and regulations.

With habituation, discipline can be formed in an individual. A disciplined student will be able to divide his time in carrying out all daily routines, obey all regulations in the environment where he is and be able to adjust to the surrounding environment.

In terms of learning, students who are disciplined will be easier in absorbing subject matter than students who lack discipline. This is because students who are disciplined in learning will always spend most of their time each day learning or useful activities. Where individual enthusiasm for learning can grow both from psychological factors and non-intellectual nature.

As stated (Winkel, 2003) cited (Puspitasari, 2012) explained understanding of learning motivation is a variety of self-made efforts that lead to activities for learning, as well as ensuring the continuity of these learning activities that give direction to their activities so that the desired goals are achieved.

Hamzah (2011), states that motivation in learning is an encouragement from within and outside the learners themselves when learning to get a change in habits. Every student during the learning process wants good learning outcomes. Where learning outcomes are changes in behavior obtained after following the teaching and learning process. To achieve good learning outcomes, each student must struggle and compete to achieve it. The problem that arises is whether students can learn by utilizing all the capabilities they have and the situations and 
conditions that exist in their environment to achieve maximum learning outcomes.

While English is a compulsory subject that must be learned by students. As the situation and conditions at SMK Bina Bangsa Kayuagung Ogan Komering Ilir (OKI) that the motivation and discipline of student learning, especially in English learning still needs to be improved considering that English learning sometimes makes students lazy to follow it well. It certainly will require encouragement from both outside and inside of students. Lack of will and feeling afraid when asked to speak English while studying, so they must be told or appointed first before they want to talk. The learning process becomes stiff and tense (Interview, 2019).

As an effort made by the school and English teachers, especially in increasing student motivation and learning discipline that is expected to have an impact on learning outcomes, namely by arranging English subjects at the beginning or at the first hour of learning. Besides that when students are given assignments given enough time so that students can complete it well and on time (Interview, 2019).

Preliminary data of observations made by the author related to this matter that the ability of students to obtain learning outcomes, especially English is still below the Minimum Mastery Criteria (KKM) which is set at SMK Bina Bangsa Kayuagung in odd semester $2019 / 2020$ is 7.0 and the condition of students when implementing teaching and learning processes that are less conducive, students do not focus on learning while learning. The non-conducive conditions include low student motivation, undisciplined learning, when students just enter the class and follow it, and consider learning English as a difficult subject, must memorize, and boring.

Pedagogical competence must be possessed by a teacher because teachers must have the ability to understand their students, be able to do learning designs and their implementation, conduct evaluations, and develop their students to bring out their potentials. So, actions that can be implemented by the teacher are doing several ways to foster motivation and discipline in learning activities at school, such as giving numbers / values, gifts, giving tests, knowing the results, praise, punishment, the desire to learn and interests. In reality everyone's motives in learning can be different from each other. There are students who study hard because they want to increase their knowledge, there are also students who study for fear of being scolded by their parents. 
Motivation and learning discipline applied in OKI Vocational School Bina Bangsa is to improve student learning outcomes or achievements, but not all students are motivated to succeed in learning and achieve maximum achievement. So there are students who have grades above the KKM and students who score below the specified KKM. So that by doing this research, the authors hope to provide an overview of teachers and students how important it is to have motivation and discipline of learning.

To achieve good quality learning, teaching and learning process must be carried out systematically and not carelessly. This is what underlies the author feels interested and needs to conduct research activities on the relationship of motivation and student learning discipline with the results of English learning in class XI students of SMK Bina Bangsa Kayuagung OKI.

This study aims to see the relationship of student motivation and discipline with learning outcomes in English of OKI Vocational School students of SMK Bina Bangsa. The results of this research are expected to be useful and useful: (1) students, the existence of learning motivation can improve learning achievement and increase knowledge about several factors that can affect their learning achievement; (2) the teacher, contributes to efforts in improving learning outcomes especially in English and other subjects in general, as well as providing knowledge about the relationship between discipline and learning motivation towards student achievement; and (3) Educational institutions as an alternative as an effort to advance the quality of learning and teacher competence.

\section{THEORITICAL FRAMEWORK}

\section{Definition of Motivation}

According to Mc. Donald (in Sardiman, 2011), it states that "Motivation is a change of self in someone who is marked by the emergence of" feeling "and preceded by a response to the existence of goals".

According to Hamzah (2011), stated that "Motive is the driving force in a person to carry out certain activities, in order to achieve certain goals. Thus motivation is the impetus that is in a person to try to conduct better behavior in meeting needs ".

Purwanto (2002), said that there are two principles for knowing one's motivation: 
a. Motivation is seen as a process. Knowledge about this process that will help us explain the behavior we observe to describe other behaviors in a person.

b. From this process we can determine a person's character by looking at clues from his behavior. Are these clues convincing enough, so they can explain other behavior.

That in motivation there are basic components, such as moving, directing and sustaining people's behavior. To move means to give strength to an individual; lead someone to act in certain ways. For example the power in memory, effective responses, and the tendency to get pleasure. Motivation also directs or channels behavior. As such it provides a goal orientation. Individual behavior is directed towards something. To maintain and sustain behavior, the surrounding environment must strengthen the intensity and direction of individual impulses and forces.

From the definitions of motivation above, it can be concluded that the notion of motivation is a driving force that can provide strength and direct the activities of a person in making an effort to achieve the desired goals. Motivating students means moving students to do something.

\section{Definition of Discipline}

The term discipline originated from Latin, namely disibel which has followers, in accordance with the development of the time the designation became, which means obedience or which involves the order. In line with this Rahman (2011) revealed that "discipline comes from English dicipline which contains several meanings. Among them are self-control, forming a moral character, correcting with sanctions, as well as a collection of several rules for regulating behavior. In the learning process it is necessary to have a disciplined attitude, Slameto (2013) revealed that "learning is a process of change obtained from the efforts made by a person to obtain a new change in behavior as a whole, as a result of his own experience in interaction with his environment".

Then according to Moenir (2010) "Discipline is a form of obedience to rules, both written and unwritten that have been set. There are two types of discipline that are very dominant according to what the individual wants. First discipline in terms of time and work discipline or deeds ". Thus the two types of discipline put forward by Moenir are unity that can not be separated and influence each other, for example if a 
child is present on time at school does not arrive late at the start of class time, but he does not immediately do things according to the conditions as students in the classroom such as not directly opening the subject book but chatting with his friend of course this will harm the child himself, so that with discipline students are encouraged to learn holistically wherever students learn.

Discipline is very important in teaching and learning activities in schools. This attitude can create a learning atmosphere that is comfortable and conducive to learning. Discipline is one of the factors that can affect learning achievement. Hasibuan (2003) mention that discipline is awareness and willingness of a person to comply with applicable norms and regulations. Without discipline, it is difficult for someone to achieve the desired goal. Because discipline is the first step to achieving an educational goal.

Anneahira (2012) also revealed that: "In the world of education, discipline is a fixed price to be paid by students. The influence of discipline on learning achievement is very large so it really needs conditioning to grow and develop a disciplined attitude to the patterns of student life".

If a student has a disciplined attitude in his learning activities, the obedience and perseverance of his learning will continue to increase so as to make learning achievement increase as well, this was also expressed by Tu'u (2004) who stated that: "learning discipline will have a positive impact on student life, encourage them to learn concrete practices in life at school and be able to adapt ". But discipline at school is not an attempt to make children withstand behavior that is not accepted at school, but rather an attempt to introduce ways or provide experiences, which ultimately leads children to own ownership of a discipline from within.

This is in line with Mas'udi (2000) who argues that "discipline is the awareness to carry out work in an orderly and orderly manner in accordance with applicable regulations with full responsibility without coercion from anyone." This is in line with Masudi (2000) who argues that "discipline is the awareness to carry out work in an orderly and orderly manner in accordance with applicable regulations with full responsibility without coercion from anyone."

From on the various opinions of the experts above, that the discipline of learning is a complicated thing to learn because it is a complex thing and has a lot to do with knowledge, attitudes and behavior. Learning discipline is a student's obedience in learning shown by actions that adhere to the rules that apply in his place both at school 
and at home so he is able to prove that he can adapt to his environment for the formation of good character and always moves in the direction more advanced so that satisfying learning achievement can be achieved. For this reason the disciplinary problem discussed in this study is the discipline carried out by students in their learning activities both at home and at school.

\section{Speaking Strategies and Good Language Learner Strategies}

It is important for students to recognize their own weaknesses and strength in learning, particularly learning a language. An ability to select and use suitable strategies in learning to speak English will help them build their ability to speak English easier and faster.

The successful of learning to speak English, especially for the learners who learn English s foreign language, is influenced by several factors. Two of them are knowledge about strategies in learning to speak and the students' ability to select the appropriate strategies for themselves. The successful in mastering these two aspects will bring the students to be good language learners. Rubin and Thomson (Nunan, 1996) characterize the good language learner strategies as follow:

1. Good learners find their own way.

2. Good learners organize information about the language.

3. Good learners are creative and experiment with the language.

4. Good learners make their own opportunities and find strategies for setting practice in using the language inside and outside the classroom.

5. Good learners learn to live with uncertainty and develop strategies for making sense of the target language without wanting to understand every word.

6. Good learners use mnemonics (rhymes, word association, etc) to recall what has been learned.

7. Good learners make error work.

8. Good learner use linguistic knowledge, including knowledge oft heir first language in mastering a second/foreign language.

9. Good learners let the context (extra linguistic knowledge and knowledge of the world) help them in comprehension.

10. Good learners learn to make intelligent guesses.

11. Good learners learn chunks of language as a whole and formalized routines to help them perform beyond their competence. 
12. Good learners learn production techniques (e.g. techniques for keeping a conversation going).

13. Good learners learn different styles of speech and writing and learn to vary their language according to the formality of the situation.

Richards and Renandya explain some considerations in the form of test of a technique's potential for creating or sustaining intrinsic motivation of which represents a facet of principle of intrinsic motivation (Richards, Jack, 2002). For instance, the technique should appeal to the genuine interests of the students, the technique should be presented in a positive, enthusiastic manner and the students are clearly aware of the purpose of the technique. Furthermore, they add that the teachers should consider whether the technique encourage students to discover for themselves certain principles or rules rather than simply being 'told' and whether it also encourage students in some ways to develop or use effective strategies learning and communication. There are some techniques that can be applied by teachers in teaching their students to speak English, such as role play (with one student-taking the role of a foreigner), naïve-speaker visitor answer questions $\mathrm{n}$ specific topics, pen friends (by mail or e-mail), group presentation, interclass debate, speech competitions, concerts (plays and singing)

\section{Definition of Learning Outcomes}

General, the understanding of learning outcomes is a change in behavior and overall ability possessed by students after learning, which manifests in the form of cognitive, affective, and psychomotor abilities (not just one aspect of the potential) caused by experience. Understanding learning outcomes is an outcome of the interaction of learning and teaching activities. The teaching activities ended with the process of evaluating learning outcomes. From learning activities that learning outcomes are the end or the top of the learning process mentioned (Dimyati and Mudjiono, 2013).

Meanwhile, according to Susanto (2013) understanding of learning outcomes is a change that occurs in students, both concerning cognitive, affective, and psychomotor aspects. Learning outcomes are learning achievements are the maximum results obtained after participating in a learning activity in which the activities are carried out in order to get good recognition of their learning efforts within a certain period of time. 
To assess student achievement a number of tests are needed. As revealed Mulyasa (2008) which states that: "The assessment of learning achievement at the classroom level is an assessment made by the teacher or educator directly. Assessment of learning achievement is basically an activity to measure changes in student behavior ".

The success of a person and vice versa in learning can be caused by many factors that can affect the achievement of learning achievement, namely factors that originate from within and from outside himself. There are factors that determine the achievement of learning achievement as suggested by Dalyono (2005) which states: (1) internal factors (originating from within) such as discipline, physical and spiritual health, interests and talents, will, and ways of learning; (2) external factors (originating from outside the self) include family, school, surrounding environment and society.

From on the experts' description above, it is stated that there are various factors that influence learning achievement, both from outside and within students, of course there is a need for harmony in the learning process between students as learners and teachers as facilitators. Thus the researcher concludes that learning outcomes are learning achievements achieved by students in the process of teaching and learning activities by bringing a change and the formation of a person's behavior. Learning outcomes as a measurement of the assessment of learning activities or he process of learning activities that are described in the form of symbols, letters or sentences that define the results achieved by students in a certain period.

\section{RESEARCH METHODOLOGY}

The research design is a quantitative descriptive approach, using cross sectional, as can be seen in the picture as follows:

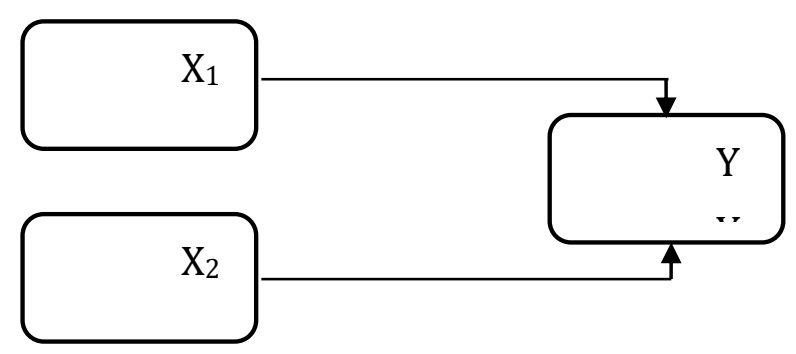

Figure 1. Research Design 
Information :

$\mathrm{X} 1=$ Learning motivation

$\mathrm{X} 2$ = Learning discipline

$\mathrm{Y} \quad$ = Learning outcomes

This research was conducted in OKI Vocational School Bina Bangsa Vocational School and was conducted on December 202018 until January 10, 2019. The number of the population is all students of class XI Vocational School Bina Bangsa Kayuagung as many as 31 students. In the sample selection the researchers used a saturated sampling technique totaling 31 students of SMK Bina Bangsa Kayuagung. Sugiyono (2017) says that: "Saturated sampling Saturated sampling is a way of selecting samples with members of the population used for the sample as a whole.

The questionnaire used in data collection uses several choices of answers from positive and negative statements : Strongly Agree (SS), Agree (S), Disagree (TS), and (Strongly Disagree (STS).

Table 1

Questionnaire Scores

\begin{tabular}{|l|c|c|c|c|}
\hline Answer category & SS & S & TS & STS \\
\hline Positive & 4 & 3 & 2 & 1 \\
Negative & 1 & 2 & 3 & 4 \\
\hline
\end{tabular}

The researcher uses secondary data taken through documentation techniques in the form of a list of students' grades in English. Data processing techniques using quantitative analysis with univariate and bivariate statistical analysis. To find out the significance of the relationship between the two variables, it is calculated by using a statistical test at the significant level of 95 and the largest error rate $(\alpha)$ of 0.05 or $5 \%$. With the following criteria: (1) there is a significant relationship between the independent variable and the dependent variable if $\rho$-value $\leq \alpha(0.05)$; and (2) there is no significant relationship between the independent variable and the dependent variable if $\rho$ value $>\alpha(0.05)$. 


\section{FINDINGS \& DISCUSSIONS}

Based on the results of the discussion frequency distribution variables motivation and student learning discipline with student learning outcomes in English is as follows:

First, frequency distribution of student motivation of 31 respondents ie there are 3 respondents (9.7\%) who have high learning motivation and as many as 28 respondents (90.3\%) who have low learning motivation. Low or high motivation to learn students can be known from many factors, this is according to the results of research conducted (Dwi Tri Santosa and Tawardjono Us, 2016) that the causes of low motivation to learn students in class XI Department of Motorcycle Engineering SMK Muhammadiyah 1 Bambanglipuro is from extrinsic factors of 51,88\% included dynamic elements in learning and learning; teacher's efforts in teaching students and the students' environmental conditions. While the intrinsic factor of $48.12 \%$ includes the condition of students; student abilities and student ideals.

Second, the frequency distribution of students' learning discipline from 31 respondents who have high learning discipline as many as 2 respondents (6.5\%) and who have low learning discipline as many as 29 respondents (93.5\%). As the results of research conducted by (Nur Halifah Djahara, Abd Munir, and Dhevy Puswiartika, 2017) that student learning discipline basically can influence the learning outcomes of class XI students of SMKN 5 Palu where the results of the research show $4 \%$ of students have very disciplined learning high, $52 \%$ of students have high learning discipline, so $44 \%$ from students have low learning discipline.

Third, the frequency distribution of learning outcomes of 31 respondents who have good learning outcomes as many as 12 respondents $(38.7 \%)$ and who have less learning outcomes as many as 19 respondents $(61.3 \%)$.

Analysis of the relationship between motivation variables and learning discipline with student learning outcomes in English is as follows:

First, the relationship of learning motivation with students' English learning outcomes at SMK Bina Bangsa Kayuagung OKI out of 12 respondents who have good learning outcomes with high motivation as much as 1 respondent (33.3\%), and students who get good learning outcomes with low motivation as many as 11 respondents ( $39.3 \%$ ). While from 19 respondents who have poor learning outcomes with low 
motivation as many as 2 respondents (66.7\%), and students who get poor learning outcomes with low motivation as many as 17 respondents (60.7\%).

From the statistical test using chi-square obtained $\rho$-value $=$ 1,000 , these results indicate that there is no relationship between motivation with English learning outcomes in class XI SMK Bina Bangsa Kayuagung OKI.

Second, the relationship of learning discipline with the results of students' English learning at SMK Bina Bangsa Kayuagung OKI from 12 respondents who have good learning outcomes with high discipline as many as 2 respondents (100\%), and students who get good learning outcomes with low discipline as many as 10 respondents (34.5\%). While 19 respondents who had poor learning outcomes with high discipline were not found $(0 \%)$, and students who obtained poor learning outcomes with low discipline were 19 respondents $(65.5 \%)$.

From the statistical test using chi-square obtained $\rho$-value $=$ 0.142 , these results indicate that have not relationship variable discipline toward English learning outcomes of students of SMK Bina Bangsa Kayuagung OKI.

The results of the calculation of student motivation variables obtained $\rho$-value $1,000(<\alpha 0.05)$, meaning the null hypothesis $\left(\mathrm{H}_{0}\right)$, which means there is no positive relationship between learning motivation with student learning outcomes OKI Vocational High School Vocational School. Likewise, the results of the calculation of student learning discipline variables obtained value $\rho$-value $0.142(<\alpha 0.05)$ means the null hypothesis $\left(\mathrm{H}_{0}\right)$, which means there is no positive relationship between learning discipline with student learning outcomes in class XI of SMK Bina Bangsa Kayuagung.

\section{CONCLUSION \& SUGGESTION}

\section{Conclusion}

Based on the results of data processing and discussion of researchers, it can be concluded that there is no positive relationship between learning motivation and student learning outcomes in English in class XI of SMK Bina Bangsa Kayuagung OKI obtained $\rho$-value 1,000 $(<\alpha 0.05)$. Not found positive relationship on the discipline variable with student learning outcomes in class XI students of SMK Bina Bangsa Kayuagung OKI obtained $\rho$-value $0.142(<\alpha 0.05)$. 


\section{Suggestion}

Based on the research findings and discussion obtained and conclusions as outlined above, some suggestions that researchers can convey as followings:

1. For students to be able to increase their curiosity and care about the acquisition of their grades, then if that happens it will be most likely to improve student learning outcomes themselves.

2. For the school to always provide opportunities and motivation for teachers to do more self-development so that they will be able to make a positive contribution to improving student learning outcomes.

3. For further researchers, it is possible to carry out further research in an effort to improve the learning outcomes of students of SMK Bina Bangsa Kayuagung, especially in English and other subjects in general.

\section{REFERENCES}

Anneahira. (2012). Pengertian Pendidikan. Tersedia: http://anneahira.com/artikel-pendidikan/. Diakses tanggal 22 September 2018.

Dalyono. (2005). Psikologi Pendidikan. Jakarta: Rineka Cipta.

Dimyati dan Mudjiono. (2013). Belajar dan Pembelajaran. Jakarta: PT Rineka Cipta.

Dwi Tri Santosa dan Tawardjono Us. (2016). Rendahnya Motivasi Belajar dan Solusi Penanganan pada Siswa Kelas XI Jurusan Teknik Sepeda Motor. Jurnal Pendidikan Teknik Otomotif Edisi XIII, Nomor 2, Tahun 2016.

E. Mulyasa. (2008). Menjadi Guru Profesional Menciptakan Pembelajaran Kreatif dan Menyenangkan. Bandung : PT. Remaja Rosdakarya.

Hamzah. B. Uno. (2011). Teori Motivasi dan Pengukurannya: Analisis di Bidang Pendidikan. Jakarta: Bumi Aksara.

Hamzah. B. Uno. (2011). Teori Motivasi dan Pengukurannya: Analisis di Bidang Pendidikan. Jakarta: Bumi Aksara. 
Hasibuan, Malayu S. P. (2003). Manajemen Dasar, Pengertian dan Masalah. Jakarta: PT. Toko Gunung Agung.

Mas'udi, Asy. (2000). Pendidikan Pancasila dan Kewarganegaraan. Yogyakarta: PT. Tiga Serangkai. http://www.sarjanaku. com/ 2010/12/kedisiplinanbelajar-siswa.html). Diakses tanggal 22 Septemebr 2018.

Moenir, A.S. (2010). Manajemen Pelayanan Umum di Indonesia. Jakarta : Bumi Aksara.

Moenir, A.S. 2010. Manajemen Pelayanan Umum di Indonesia. Jakarta : Bumi Aksara.

Nunan, D. and Clarice Lamb. (1996). The Self-directed Teacher: Managing the learning process. New York: Cambridge University Press.

Nur Halifah Djahara, Abdul Munir, dan Dhevy Puswiartika. (2017). Hubungan antara Motivasi Belajar dengan Disiplin Belajar Siswa Kelas XI SMKN 5 Palu. Jurnal Konseling \& Psikoedukasi Volume 2, Nomor 1, Juni 2017. e-ISSN: $2502-4000$.

Purwanto M. N. (2002). Prinsip-prinsip dan Teknik Evaluasi Pengajaran. Bandung: PT Remaja Rosdakarya.

Puspitasari, D dan Isriani H. (2012). Strategi pembelajaran tepadu. Yogyakarta: FAMILIA.

Rahman, Masykur Arif. (2011). Pentingnya Disiplin Belajar. Jakarta : Rineka Cipta.

Richards, Jack. C and Willy Renandya. (2002). Methodology in Language Teaching. An Anthology of Current Practice. Cambridge: Cambridge University Press

Sardiman. A. M. (2011). Interaksi dan Motivasi Belajar Mengajar. Bandung: Rajawali Pers.

Sardiman. A. M. (2011). Interaksi dan Motivasi Belajar Mengajar. Bandung: Rajawali Pers.

Slameto. (2013). Belajar dan Faktor-faktor yang Mempengaruhinya. Jakarta: PT Rineka Cipta.

Sugiyono. (2017). Metode Penelitian Kuantitatif, Kualitatif, dan R\&D. Bandung: Alfabeta. 
Puji Astuti: Relationship Betwen Motivation and Discipline of Students to Student Learning Outcomes Class XI Vocational High School|15

Susanto, Ahmad. (2013). Teori Belajar dan Pembelajaran di Sekolah Dasar. Jakarta: Kencana Prenadamedia Group.

Tu'u, Tulus. (2004). Peran Disiplin pada Perilaku dan Prestasi Siswa. Jakarta: Grasindo. 
16 | ENGLISH FRANCA, Vol. 4, No. 1, 2020 